\title{
ZNACZENIE HISTORII W STUDIACH REGIONALNYCH: ROLA PRZESZŁOŚCI W POLSKIEJ SOCJOLOGII REGIONU PO ROKU 1989
}

\section{WPROWADZENIE}

Współczesne studia regionalne charakteryzują się podejściem skoncentrowanym na problemie, skłonnym do poszerzania aspektów badanych zjawisk i łączenia różnych sposobów analizy. Prowadzi to do korzystania z dorobku innych dyscyplin, spośród których szczególnie dużą rolę odgrywa historia. Rosnące znaczenie kontekstu globalnego zachęca do postrzegania zjawisk społecznych nie tylko w konkretnej przestrzeni, ale i w określonym punkcie procesu historycznego.

Studia nad rozwojem regionalnym ewoluują w kierunku holistycznych ujęć uwzględniających czynniki kulturowe i warstwę symboliczna. Nowi teoretycy regionalizmu, osadzeni w nurcie krytycznym i konstruktywistycznym, podkreślaja, że regionów nie można traktować jako czegoś oczywistego, naturalnego i obiektywnego. Mają raczej charakter procesów, nieustannie podlegają konstruowaniu w sferze symbolicznej ${ }^{1}$. W tym ujęciu przeszłość może być przedmiotem badania jako kluczowy zasób kulturowy. Odgórne działania władz spotykają się z aktywnością oddolna, a różne rozumienia tożsamości regionalnej konfrontują się ze sobą. Można widzieć to jako proces wzajemnych negocjacji i uzgadniania zinstytucjonalizowanych praktyk dyskursywnych, które mają wyraz we wdrażanych politykach regionalnych ${ }^{2}$.

Przedmiotem analizy jest dorobek socjologicznych studiów regionalnych w Polsce. Śledząc drogę ich rozwoju w ostatnich trzech dekadach, chcę zwrócić uwagę na wyraźną obecność przeszłości w przedstawianych tam interpretacjach. Wydaje się, że pełni ona w nich istotne funkcje. Główne pytanie dotyczy zastosowań i sposobów przywoływania i analizowania przeszłości w dyskursie socjologicznym. Ciekawi mnie, w jaki sposób badacze do niej sięgają. Czy przeszłość w tych analizach jest w ogóle przedmiotem badania, czy raczej jest używana instrumentalnie? Jakie spełnia więc zadania i jakim tezom służy? Jakie wydarzenia i zjawiska z przeszłości pojawiają się najczęściej? Czy użycie przeszłości przez socjologów ma jakieś wspólne punkty z praktyką badawczą historyków? Czy następuje ewolucja w sposobach i celach sięgania do historii

\footnotetext{
1 Soderbaum, Shaw (2003).

2 Np. Paasi (2013).
} 
polskich regionów? Zamierzam odpowiedzieć na te pytania w dwóch obszarach socjologicznych badań nad regionami. Pierwszy wyznaczają analizy związane z rozwojem regionalnym. Drugi stanowi nurt badań tożsamości regionalnych, zwłaszcza zaś ich trwałych kulturowych składników, jak tradycje lokalne.

W polskich analizach społecznych zainteresowanie przeszłością wydaje się narastać od kilkunastu lat. Na początku transformacji uwaga była zwrócona ku przyszłości i skupiona na założonym efekcie przemian. Myślano prospektywnie, przyjmując obraz przyśpieszonej modernizacji na wzór zachodni, w którym następowało swoiste sprasowanie czasu. Analizy socjologów często polegały na porównaniach aktualnego stanu z założonym końcowym efektem przemian. W tym raczej technokratycznym podejściu przeszłość pojawiała się rzadko, wyłącznie w kontekście utrudnień i blokad, ulokowanych w postsocjalistycznych deficytach mentalnych Polaków. Społeczeństwo postrzegano jako ten obszar rzeczywistości, który stawiał opór przemianom i był źródłem utrudnień w realizacji zamierzonego projektu modernizacyjnego.

Dopiero perspektywa integracji europejskiej skłoniła do dostrzeżenia dalszego horyzontu historycznego, sięgającego, poprzez okres zaborów, aż do momentu rozejścia się dróg rozwojowych Europy Wschodniej i Zachodniej w XVI w. Przypomniano sobie o historycznym zacofaniu gospodarczym, opóźnionych procesach modernizacyjnych, słabej industrializacji, niekorzystnych skutkach braku państwa czy nienowoczesnej strukturze społecznej. Europa Wschodnia, dotąd określana głównie przez doświadczenie komunizmu, została postawiona wobec konieczności porównań z resztą świata i określenia się w ramach projektu europejskiego. Warto przywołać uwagę Anny Sosnowskiej, która już w 1997 r. zauważyła, że stosunek do peryferyjnego położenia kraju stał się ważnym źródłem różnic politycznych ${ }^{3}$. Problem peryferyjności uznaje się dziś za jedną z zasadniczych kwestii, która wytwarza podziały w polskiej przestrzeni publicznej i określa myślenie o regionach. Ta perspektywa pociaga za sobą potrzebę myślenia historycznego.

$\mathrm{W}$ okresie transformacji również polityka regionalna i regionalizm weszły w nowy etap. Przedtem socjalistyczna centralizacja i polityka wyrównywania różnic rozwojowych raczej zacierały czynniki odpowiedzialne za odmienności przestrzenne. Regionalizm jako reprezentacja partykularnych interesów grupowych był postrzegany jako zagrożenie dla nadrzędnych celów państwa i propagowanej idei jedności ${ }^{4}$. Upadek centralnie sterowanej gospodarki ujawnił istniejące różnice regionalne, a otwieranie się Polski na wpływ zjawisk globalnych istotnie wzmocniło znaczenie przestrzennego zróżnicowania. W rozpatrywaniu szans rozwojowych zaczęły się liczyć regionalne przewagi konkurencyjne. Wreszcie liberalizacja polityczna i rozwój demokratycznych mechanizmów na wszystkich, także lokalnych, poziomach stworzyły nowe możliwości kreowania polityki i budowania lokalnych instytucji i lokalnych tożsamości. W późniejszym czasie integracja europejska istotnie przyczyniła się do zjawiska tworzenia regionów, wyposażając je w realne zasoby $\mathrm{i}$ istot-

\footnotetext{
3 Sosnowska (1997).

${ }^{4}$ Gorzelak (1993): 47.
} 
nie je wzmacniając. Zarysował się nowy pakiet problemów badawczych, jak kwestie zarządzania i samorządności regionalnej, nowej polityki regionalnej, integracji terytorialnej, budowania tożsamości i pamięci regionalnej.

\section{ROZWÓJ REGIONALNY I RÓŻNICE HISTORYCZNE}

Wraz z badaniami nad rozwojem regionalnym pojawiły się pytania o uwarunkowania regionalnego zróżnicowania i szanse przezwyciężenia blokad rozwojowych. Pytanie o miejsce Polski w nowym porządku europejskim przypomniało trwałość i aktualność historycznych różnic rozwojowych. W polskiej debacie publicznej pojawiły się idee podziału na „trzy Europy” Jeno Szucsa ${ }^{5}$. Powrócono do dawnych rozważań Oskara Haleckiego o odmiennych częściach naszego kontynentu ${ }^{6}$. Rozpoczęła się dyskusja nad nowym znaczeniem kategorii Europy Środkowo-Wschodniej, która była częścią szerszej debaty angażującej pisarzy, intelektualistów i dysydentów. Przeciwstawiali się dominującemu wtedy utożsamieniu tego obszaru ze Związkiem Radzieckim, a wcześniej Rosja, a także poszukiwali nowego usytuowania Polski w Europie ${ }^{7}$

Jednocześnie przygotowania do reformy terytorialnej organizacji kraju ożywiły debatę nad regionalnymi podziałami w obrębie Polski. Już w 1996 r. Bohdan Jałowiecki postawił szereg pytań, które na długo określiły katalog problemów badawczych w studiach regionalnych. Dotyczyły tego, jak daleko należy sięgać $\mathrm{w}$ przeszłość $\mathrm{w}$ celu wyjaśnienia współczesnych zróżnicowań, na czym polegają różnice i jaka jest ich rozpiętość, jaki jest udział czynników kulturowych i społecznych w rozwoju regionów oraz które regiony mają większe, a które mniejsze szanse na rozwój. W odniesieniu do nowych regionalnych ruchów społecznych pytał o ich podłoże: czy jest ono trwałe, wynikające z poczucia tożsamości terytorialnej, czy może ożywiane jedynie ideologią ad hoc? ${ }^{8}$ Szkicujacc zarys odwołań historycznych w badaniach nad regionami, uznał, że na obecny kształt procesów gospodarczych w regionach miały wpływ zasadniczo dwa okresy historyczne: przedrozbiorowy, odpowiedzialny za trwały podział na część zachodnią i wschodnią kraju, oraz kluczowy dla współczesnej mapy gospodarczej Polski etap industrializacji w drugiej połowie XIX w. W badaniach zróżnicowania przestrzeni Polski przyją się podział na cztery historyczne makroregiony: Kongresówkę, Wielkopolskę, Galicję i Ziemie Zachodnie. Wytworzyły one specyficzne struktury gospodarcze i infrastrukturę. Historia zaborów jest jednak stosowana także do wyjaśniania postaw i zachowań społecznych oraz profilów politycznych wyborców ${ }^{9}$.

\footnotetext{
5 Szucs (1995).

${ }^{6}$ Halecki(1994).

7 Kundera (1984); Miłosz (1990). Więcej o przebiegu debaty: Sosnowska (2004): 134-146.

8 Jałowiecki (1996a): 5.

9 Jałowiecki (1996b): 36-37.
} 
Podobnie jakość zarządzania na poziomie gmin i sprawność samorządów jest odnoszona do różnic wynikających z granic zaborowych ${ }^{10}$. W tych przypadkach trudniej uzasadnić, jak zostały przeniesione i utrwalone te niematerialne, czysto kulturowe odmienności. Dominuje schemat dyfuzji kulturowej, zakładający, że historyczny proces przyjmowania kapitalistycznych wzorów aktywności gospodarczej postępował w Polsce stopniowo w kierunku wschodnim, zatem regiony położone bardziej na zachód posiadają nie tylko bogatsze wyposażenie materialne i wyższy poziom zamożności, lecz także inny, bardziej odpowiedni do wyzwań gospodarki rynkowej typ nastawień i osobowości $^{11}$. Regionalne różnice poziomu rozwoju gospodarczego są zwykle wiązane z historycznymi danymi dotyczącymi wskaźników postępu urbanizacji, odsetka ludności zajmującej się handlem i rzemiosłem, wydajności produkcji rolnej czy postępów industrializacji ${ }^{12}$. Szczególne znaczenie przypisuje się XIX stuleciu jako epoce rewolucji przemysłowej i powstania nowoczesnych państw narodowych oraz towarzyszącemu im rozwojowi sieci nowoczesnych instytucji. Te motory wielkich zmian modernizacyjnych traktuje się jako zjawiska formatywne dla współczesnych dystansów rozwojowych. Widzi się je najczęściej w sposób deterministyczny, przyjmując, że „ich zmiana wymagałaby cofnięcia historii, co jest niemożliwe"13. Ten nieusuwalny ciężar przeszłości jest ujmowany jako pułapka zacofania i źródło problemów, które są właściwie nie do przezwyciężenia. W studiach nad współczesnym rozwojem regionalnym stosuje się powszechnie obowiązującą wizję polskich dziejów, w której wkroczenie w XVI w. na odmienną od Zachodu Europy ścieżkę przemian gospodarczych, potem utrata państwowości oraz opóźniona industrializacja w końcu XIX w. są głównymi punktami trajektorii zacofania gospodarczego.

W szacowaniu potencjałów rozwojowych regionów ta perspektywa dominuje. Przeszłości używa się też w studiach nad regionalną sferą publiczna i aktywnością polityczną Polaków. Parę lat po jej odrodzeniu zaobserwowano przestrzenne prawidłowości zachowań wyborczych i profilów politycznych. Tomasz Zarycki dostrzegł, że nakładają się na podziały zaborowe. Tereny tzw. Ziem Zachodnich i Północnych stanowią czwarty region o osobnym profilu ${ }^{14}$. Uznał, że różne dzieje zaborów są odpowiedzialne za współczesne różnice. Dalsze uzasadnienie tej tezy można znaleźć w badaniu Jerzego Bartkowskiego na temat wpływu tradycji na zachowania wyborcze i postawy społeczne ${ }^{15}$. Aby uwzględnić obecność elementów z przeszłości w dzisiejszej kulturze społeczności lokalnych, zastosował on teorię podłoża historycznego Kazimierza Dobrowolskiego. Uznał, że przełom XIX i XX w. był dla ziem polskich okresem nie tylko modernizacji gospodarczej, lecz także społecznej, odmiennie przebiegającej w trzech kontekstach zaborowych. Bartkowski przeanalizował specyfikę wzorów działania zbiorowego, ukształtowanych pod koniec XIX w. w każdym

\footnotetext{
${ }^{10}$ Np. Gorzelak (2016); Smętkowski, Płoszaj (2016).

${ }^{11}$ Hryniewicz (1996); Gorzelak, Tucholska (2008).

${ }^{12}$ Hryniewicz (1996); por. Hryniewicz (2015).

${ }^{13}$ Zarycki (1999): 99.

${ }^{14}$ Zarycki (2002).

${ }_{15}$ Bartkowski (2003).
} 
z makroregionów. Badał regionalne zróżnicowanie zachowań wyborczych i preferencji politycznych. W wieloaspektowej i gruntownej analizie obejmującej okres od drugiej połowy XIX w. do współczesności oparł się nie tylko na dostępnych opracowaniach historycznych, ale także na istniejących relacjach z epoki i ówczesnej literaturze pięknej.

Zarówno Zarycki, jak i Bartkowski zaproponowali ujęcie kontekstowe, według którego otoczenie kulturowe jednostki wpływa na nadawanie sensów działaniom, a przez to modyfikuje sposoby postępowania. Wiele składników tego kontekstu jest usytuowanych w tradycji. Oznacza to, że wywodzą się z przeszłości, trwając w zasadniczo niezmienionej postaci od ponad stulecia, by dziś także kształtować postawy i działania kolejnych pokoleń. Obaj badacze zestawili cztery historyczne makroregiony, jednakże ich celem nie było nakreślenie kompletnych trajektorii procesów społecznych. Wybrali tylko kluczowe momenty w przeszłości, koncentrując się na końcu XIX w. Taki sposób postępowania jest dość częsty w badaniach nad odmiennościami regionalnymi. Także w międzynarodowych badaniach porównawczych Europy postkomunistycznej w podobny sposób uwzględniono wpływ odmiennych historii na proces instytucjonalnego konstruowania regionów. Ramą analiz była koncepcja trzech megaregionów w Europie postkomunistycznej, wywodzacych się z różnych ścieżek historycznego rozwoju: wschodniej, zachodniej i południowej. W tym ujęciu nie tylko instytucje, lecz także tożsamości regionalne są zdeterminowane dziedzictwem przeszłości ${ }^{16}$. Schemat ten jest prosty i stereotypowy, nie ma w nim miejsca na pogłębione analizy historyczne.

W tych badaniach przeszłość determinuje teraźniejszość. Jednakże to powiązanie ogranicza się do wskazania na czynniki kształtujące mechanizmy społeczne, np. w końcu XIX w. i uznania ich za istotne dla obecnych zróżnicowań, najczęściej mentalnych. Niejasne pozostają mechanizmy, za sprawa których przeszłe formy oddziałują na obecne postawy i postępowanie ludzi. Badacze nie konstruują dróg, za pomoca których instytucje czy wydarzenia z określonego punktu w przeszłości „przeniosły” swój wpływ przez dekady innych zdarzeń i procesów aż do dzisiejszego momentu. O ile łatwiej dostrzec takie powiązania w przypadku materialnego potencjału ekonomicznego, rozwoju infrastruktury czy dorobku instytucjonalnego, to wpływ konkretnej przeszłości na subiektywne zjawiska kulturowe nie jest wyjaśniony.

\section{TOŻSAMOŚCI REGIONALNE JAKO KONSTRUKTY BUDOWANE WOKÓŁ PRZESZŁOŚCI}

Wobec rozwoju polityki regionalnej i rosnącego dorobku samorządów zagadnienie tożsamości regionalnej przestało być tylko tematem socjologicznych diagnoz ${ }^{17}$, a zaczęło być przedmiotem projektów ideologicznych. Potraktowane

16 Tatur (2004).

17 Dorobek socjologii polskiej na temat tożsamości regionalnej jest obfity - por. Starosta (1999). Akcentuje się w nim subiektywny aspekt identyfikacji, na który w dużym stopniu składa 
jako lokalny kapitał, tożsamości stały się obiektami konstruowania, adaptowania i wykorzystania przez liderów w różnych kontekstach. Traktując kulturę jako rodzaj zasobu, który może służyć realizowaniu celów grupowych czy mobilizacji społecznej, lokalne elity dostrzegają w niej instrument zarządzania. Tożsamości i więzi lokalne mogą być wzmacniane i ukierunkowane przez narracje o przeszłości. Okazało się to ważne, zwłaszcza że w świetle ustaleń Bohdana Jałowieckiego i Marka S. Szczepańskiego z 2000 r. tożsamość regionalna Polaków była „słaba i rozmyta”, a identyfikacje miały jedynie charakter werbalny ${ }^{18}$. W efekcie w pierwszych latach po reformie samorządowej mieliśmy do czynienia z „tożsamościowym wzmożeniem”, polegającym na konstruowaniu odgórnych projektów kreujących regionalne ideologie i obrazy wspólnot lokalnych na podstawie odczytywanej na nowo historii. Ważnym aspektem tego nurtu był wzrost znaczenia tożsamości etnicznych. Odrodzenie tych identyfikacji po 1989 r. sprzyjało budowaniu odrębności regionalnych, a nawet ruchu społecznego. Socjologowie prowadzacy badania kaszubskiej i śląskiej tożsamości szczegółowo rekonstruują historię tych regionów ${ }^{19}$. Nie sposób dokonać socjologicznej analizy kształtowania się tożsamości na Śląsku czy na Kaszubach bez dogłębnej interpretacji przeszłości tych regionów, zarówno tej przeżywanej przez jednostki, jak i będącej jej uwspólnioną wersja. Jest ona częścia współczesnych identyfikacji, a także budulcem publicznego o nich dyskursu ${ }^{20}$.

Szczególne zainteresowanie skupiało się na regionach o problematycznej i złożonej tożsamości, przed którymi stało zadanie jej rekonstrukcji. Tak było z Ziemiami Zachodnimi, które po zerwaniu ciagłości społecznej i kulturowej podlegały istotnym zmianom i potrzebowały nowej polityki tożsamościowej. Najnowsze analizy procesu powstawania tożsamości regionalnej mieszkańców Warmii i Mazur ukazują rozłożony na dekady proces instytucjonalizacji i inne kulturowe mechanizmy konstruowania nowego regionu. Rekonstruowanie i modelowanie przeszłości stało się ich znakiem firmowym. Po odrzuceniu przyjmowanej w czasach PRL narracji o pomyślnej i szybkiej integracji przyjęto obraz złożonego i długotrwałego procesu powstawania regionów Ziem Zachodnich. Wojciech Łukowski swoją typologię identyfikacji mieszkańców regionu osadził w formacyjnych wydarzeniach od końca II wojny, poprzez okres PRL, aż do transformacji ustrojowej i zbliżającej się akcesji do Unii Europejskiej ${ }^{21}$. Jacek Poniedziałek zaangażował wiedzę historyczna jeszcze bardziej. Korzystając z opracowań historyków, dorobku socjologicznych badań z okresu PRL oraz zasobu gromadzonych przez lata materiałów biograficznych, skonstruował

\footnotetext{
się kontekst kulturowy, w tym historyczny (Rybicki 1979). Przeszłość była np. dla Ossowskiego (1967) niezbędnym elementem opisu więzi regionalnej na Śląsku Opolskim czy historycznie zmiennej relacji między ojczyzną prywatną a ideologiczną. Podobnie Kłoskowska (1996), analizując identyfikacje narodowe i ich aspekty, jak konwersje, pogranicza i sytuacje mniejszości narodowych, osadza badane przypadki w kontekście historycznym.

18 Jałowiecki, Szczepański (2001): 195.

${ }^{19}$ Np: Synak (1998); Nijakowski (2002); Szczepański, Śliz (2018).

${ }^{20}$ Obszerną analizę historyczną zawiera np. Nijakowski (2002) o tożsamości śląskiej.

${ }^{21}$ Łukowski (2002).
} 
trajektorię kolejnych etapów procesu powstawania regionu. W tym ujęciu przeszłość nie stanowi ograniczenia dla współczesnej aktywności. To właśnie analizując przeszłość, można uchwycić podmiotowość mieszkańców Warmii i Mazur, mozolnie wytwarzających nowe identyfikacje. Warto zauważyć, że przeplataja się tutaj tożsamości oddolnie i spontanicznie budowane w toku kolejnych dekad z projektami ideologicznymi promowanymi przez regionalne elity.

Andrzej Bukowski w pracy o wytwarzaniu małopolskiej podmiotowości regionalnej podobnie wyróżnił dwie ścieżki konstruowania tożsamości ${ }^{22}$. W obu wymiarach przeszłość okazała się ważną areną kreacji tożsamości regionalnej: $\mathrm{w}$ pierwszym jako przedmiot zarządzania, a w drugim jako miejsce przeżywania identyfikacji mieszkańców z regionem.

Badania regionalnych tożsamości mają też postać porównań, obszarów skontrastowanych pod względem zaawansowania procesów modernizacyjnych. Porównanie zachodniego i wschodniego pogranicza jest oparte na obrazie dyfuzji kulturowej. Wychodząc z założenia, że transformacja systemowa obudziła uśpione uwarunkowania zachowań jednostkowych i zbiorowych, Irena Machaj zapytała o kulturowe przyczyny mniejszego tempa przemian społeczno-gospodarczych we wschodnich regionach kraju ${ }^{23}$. Źródła tych różnic zostały umiejscowione w przeszłości. Przerwanie ciagłości historycznej w 1945 r. potraktowano jako czynnik skutecznej zmiany i szansy na przedsiębiorcze nowoczesne postawy. Zdaniem autorki na wschodzie kraju ciagłość kulturowa wytwarza mocne wspólnoty, nieprzygotowane do wyzwań współczesności z powodu zakotwiczenia w dziedzictwie kulturowym i nastawienia na jego konserwowanie. Na pograniczu zachodnim wykształcenie się postaw otwartości na zmianę, adaptacji do inności i pragmatyzmu zostało powiązane z efektami przesiedleń powojennych i konieczności radzenia sobie w nowym środowisku społecznym. Doświadczenie zerwania ciagłości stworzyło tam typ tożsamości otwartej na inność i współdziałanie, nastawionej na awans społeczny. Jej cechą jest więc wydobycie się spod ciążenia tradycji. Zerwanie z przeszłościa przeobraziło mieszkańców Ziem Zachodnich w nowoczesnych Europejczyków.

Wizerunek regionu jest atutem w rywalizacji o uznanie i prestiż, co przekłada się na pozycję w walkach politycznych czy konkurowaniu o zasoby ekonomiczne. Zatem wytworzony przez badaczy obraz regionu nowoczesnego, odrzucajaccego brzemię tradycji i dobrze adaptującego się do współczesnych wyzwań może wspierać jego pozycję i pomagać w grach o uznanie. Już ponad dekadę temu Zarycki zwrócił uwagę na polityczny charakter interpretacji najnowszej historii Polski i rozbiorów w kontekście rozwoju regionalnego. Charakterystyczne były kontrastujące obrazy dziedzictwa dwóch regionów: Galicji oraz Ziem Zachodnich i Północnych, różne w zależności od przekonań politycznych. Dla opcji prawicowo-konserwatywnej Galicja symbolizuje cenione tradycyjne wartości, podczas gdy Ziemie Zachodnie reprezentują nowoczesność i nastawienie na zmianę w wersji liberalnej i lewicowej ${ }^{24}$.

\footnotetext{
22 Bukowski (2011): 191.

23 Machaj (2005): 88.

24 Zarycki (2007).
} 
Wzbudzające dziś pozytywne skojarzenia mity wielokulturowości są często wykorzystywanym narzędziem wizerunkowym, niemożliwym do zbudowania bez uwzględnienia odległej przeszłości. Tak dzieje się w przypadku promocji Gdańska czy Wrocławia, a także Lublina i Białegostoku. W socjologicznych studiach tożsamości miast uznaje się za oczywiste włączenie opisu dziejów, często będącego obszerną „biografią miasta” ${ }^{25}$. Dostarcza ona materiału do rekonstrukcji narracji o mieście czy prowadzonych gier wizerunkowych. Przeszłość jest też zasobem, za pomocą którego odczytuje się i waloryzuje współczesna przestrzeń miejską.

Poniedziałek na przykładzie Warmii i Mazur pokazał, jak kształt terytorialny regionu został przełożony na język mitu. Tradycje wynajduje się, korzystając z dostępnych zasobów, wśród których przeszłość pełni kluczowa rolę. Przyjmowana przez zbiorowość wersja historii pełni wiele funkcji. Służy społecznej i politycznej mobilizacji mieszkańców, ułatwia ich integrację ${ }^{26}$. Te praktyki stały się przedmiotem krytycznych, ujawniających ich legitymizacyjne i perswazyjne funkcje, analiz. Dostrzega się, że stosowane w strategiach promocyjnych mechanizmy dyskursywne mają na celu przekształcenie regionu „w rozpoznawalny produkt, markę rekonstruującą i mitologizującą rzeczywiste lub wyimaginowane cechy kulturowe terytorium, które mogą zostać wykorzystane $\mathrm{w}$ ubieganiu się o zasoby dostępne w zglobalizowanej przestrzeni społeczno-ekonomicznej”27. Ten proces przekłada kulturę i tradycję, także więc wizje przeszłości, na atut ekonomiczny i marketingowy.

Walka symboliczna i rywalizacja wizerunkowa dotyczy w szczególności regionów słabszych, ekonomicznie mniej efektywnych, borykających się z problemami rozwojowymi. Należą do nich wschodnie województwa Polski. Atrybut wschodniości używany jest często jako synonim zacofania, biedy, niezdolności do rozwoju i słabego wyposażenia kulturowego. Te stygmatyzujące interpretacje są obecne także w tekstach akademickich, w których Polska dzieli się na dwie części, zobrazowane w metaforze „Polskich tygrysów” i „Polskich susłów”28. Wschodnie województwa opisywane sa jako ta część kraju, w którym siła przeszłości i czynników zacofania jest nie do pokonania. Poza niższym poziomem rozwoju gospodarczego socjologowie wskazuja na nienowoczesny charakter wzorów działania i nastawień wobec rzeczywistości. Te postawy wyjaśnia się przygniatającym dziedzictwem zacofania i siłą tradycjonalizmu, a znacznie rzadziej dostrzega się współczesne uwarunkowania strukturalne i niekorzystne, peryferyjne położenie ${ }^{29}$. Zatem socjologowie wykorzystują wizje przeszłości do oceniania mieszkańców różnych regionów. A że nie sposób zmienić biegu dziejów, to i niełatwo przezwyciężyć ten rodzaj stygmatyzacji.

Narracje regionalne na wschodzie Polski, szczególnie oficjalne, kreujące atrakcyjny wizerunek województwa usiłują przezwyciężyć ten powszechny stygmatyzujący rys. W działaniach promocyjnych próbuje się dokonać prze-

\footnotetext{
${ }_{25}$ Bierwiaczonek et al. (2017).

${ }^{26}$ Poniedziałek (2011).

27 Gąsior-Niemiec (2004): 21.

28 Szczepański, Ślęzak-Tazbir (2009): 340-347.

29 Kolasa-Nowak (2011).
} 
wartościowań i w tym celu także sięga się do materii historycznej, podobnie wybiórczo i użytkowo, eksponując na przykład wielokulturową przeszłość regionu. Takie gry wizerunkowe są rozpoznawane przez badaczy, którzy ujawniają zawarte w nich instrumentalne podejście do historii ${ }^{30}$.

Wytwarzane w naszej części Europy ideologie wschodniości stały się przedmiotem obszernego studium Zaryckiego ${ }^{31}$. Ich głównym tworzywem jest przeszłość, która służy do tworzenia uzasadnień. Kwestionuje powszechną tendencję postrzegania problemów Polski wschodniej jako będących naturalną i oczywista konsekwencją historii niedorozwoju. Chodzi zwłaszcza o zbyt łatwe powiązanie zacofania gospodarczego ze szczególnym typem zachowań społecznych i specyficzną mentalnością. Słabość empirycznej podbudowy takich arbitralnych rozstrzygnięć jest dla Zaryckiego wskaźnikiem wewnętrznej orientalizacji, obecnej również w dyskursie akademickim. Przekonuje on, że narracje o przeszłości sa częścią strategii dyskursywnych, które narzucają ideologiczne obrazy wschodnich regionów. Przeszłość jest obiektem rywalizacji i manipulacji wyrażającej symboliczną dominację centrum nad obszarami peryferyjnymi. Zdaniem Zaryckiego mamy do czynienia z procesem zawłaszczania przez centrum opisów dokonywanych na peryferiach, to znaczy tworzenia centralnej wersji lokalnych historii. Jednocześnie na poziomie regionalnym istnieje praktyka kompensowania słabszej pozycji ekonomicznej czy politycznej przez dowartościowanie miejscowych zasobów kulturowych, które bardzo często dotyczą przeszłości. Oznacza to, że w regionach wschodnich polityka lokalna, zwłaszcza tożsamościowa i wizerunkowa, częściej nawiąuje do historii ${ }^{32}$.

Przeszłość jest ważnym regionalnym kapitałem tożsamościowym. Jej opis często jest kluczowym składnikiem badań tożsamości regionalnych. Podlega wielokrotnemu rekonstruowaniu, aby pełnić różne funkcje praktyczne, legitymizować, uzasadniać, dostarczać argumentów w sporach i rywalizacji, budować wyobrażenia integrujące wspólnotę.

\section{PODSUMOWANIE}

Jaką więc funkcję pełni dzisiaj przeszłość w badaniach regionalnych? W analizach rozwoju regionalnego odwołania do przeszłości zwykle służą podkreśleniu ograniczonej możliwości zmiany - zarówno instytucji, jak i indywidualnych sposobów działania. Zależność od przebytego szlaku uznaje się za przeszkodę niemożliwą do pokonania. Wydaje się, że rosnące uznanie przeszłości ma związek z coraz bardziej realistycznymi ujęciami przemian społecznych w Polsce. Ujawniajace się trwałe dysproporcje potencjału Polski wobec Zachodu są objaśniane wizją opornego balastu przeszłości.

\footnotetext{
30 Gąsior-Niemiec (2013).

31 Zarycki (2014).

32 Zarycki (2005).
} 
Historia gospodarcza, jak się zdaje, uzasadnia trwałość różnic w rozwoju regionów i odmienne potencjały na przyszłość. Najczęściej stosowany model dyfuzji kulturowej odpowiada wizji procesu modernizacji jako westernizacji. Perspektywy rozwojowe są powiązane z geograficzną bliskością przyjmowania wzorów zachodnich. Historia, zwykle w postaci momentu rozejścia się gospodarki europejskiej w wieku XVI czy upadku polskiej państwowości w XVIII jest odczytywana jako definiująca szanse współczesnego rozwoju. Jest to dość deterministyczne spojrzenie na rolę przeszłości, zarówno w odniesieniu do struktur, instytucji ekonomicznych i politycznych, jak i w przypadku dziedziczenia postaw i mentalności. Ta perspektywa raczej ogranicza możliwości przezwyciężenia historycznego ciężaru zacofania i dokonania zmiany. Podmiotowość ludzi jest w tym ujęciu niewielka, a wydaje się, że zróżnicowanie regionalne jest dość trwałe. Przeszłość w tych analizach to zwykle zasób ustalonej wiedzy historycznej, z którego socjologowie czerpia, by połączyć dwa punkty w czasie: wybrany moment z przeszłości i stan obecny. Raczej nie skupiają się na szczegółowym odtworzeniu drogi, która była konieczna, aby dawny czynnik zachował swój wpływ do dzisiaj. O ile wobec nieodległych epok taki skrót można uznać za uzasadniony, o tyle na przykład bezpośrednie łaczenie zasięgu placówek cysterskich w XIV w. ze współczesną mapą regionalnej aktywności gospodarczej wydaje się mało przekonujące ${ }^{33}$.

W studiach nad tożsamościami regionalnymi znacznie więcej miejsca i uwagi poświęca się przeszłości. Analizuje się ją jako obszar tworzenia rzeczywistości społecznej. Skupienie na konkretnych wydarzeniach i opis specyficznych dróg przemian ukazuje formatywny wpływ ludzi na procesy regionalne. Dobrym przykładem jest narracja o Ziemiach Zachodnich, w której socjologiczne badania rozszerzono na cały okres powojenny. Dzięki temu można pokazać proces przetwarzania zastanych okoliczności początkowych $\mathrm{w}$ działaniach i interakcjach mieszkańców, a współczesne efekty tworzenia regionów są skutkiem aktywnej adaptacji i wypadkową wielu czynników rozłożonych w czasie. Tutaj socjologowie nie tylko korzystają z ustaleń historyków, ale sami tworzą wiedzę o przeszłości, badając źródła historyczne oraz analizując narracje biograficzne osadników. Przeszłość jest rekonstruowana jako złożony proces przemian, w którym każdy kolejny krok ma znaczenie. Sięga się do niej, aby zarysować unikalną drogę wiodącą do współczesności, a raczej rzadziej, aby ocenić, czy blokowała lub ułatwiała możliwości rozwojowe.

Zasoby przeszłości są głównym budulcem tożsamości regionalnych, narzędziem integracji i regionalnego marketingu. Historia pojawia się więc jako ważny składnik polityk lokalnych i regionalnych dyskursów. Socjologowie rozpoznają także i te mechanizmy, badając, jak przeszłość pełni rolę narzędzia w grach kulturowych i rywalizacji o lepszy wizerunek regionu. Dekonstruuja sposoby jej pragmatycznego i instrumentalnego używania. Przedmiotem ich krytycznych analiz są także teksty naukowe.

Jeśli spojrzeć na epoki historyczne, nie dziwi dominacja wieku XIX, był to bowiem okres kluczowy dla powstania nowoczesnych państw i przemysłu.

${ }^{33}$ Zdun (2018): 123-134. 
Podział zaborowy jest najważniejszym punktem odniesienia. Natomiast właczenie nowych obszarów po II wojnie i historia Ziem Zachodnich to główne powody sięgania do dziejów najnowszych.

Socjologiczne badania regionalne na ogół czerpią z zasobu faktów i interpretacji ustalonych przez historyków. Raczej nie wzbogacają wiedzy o przeszłości i mało wśród nich jest projektów interdyscyplinarnych. Jednakże ogólne przekonanie o kluczowej roli przeszłości dla zrozumienia cech regionów zaczyna przybierać kształt konkretnych pytań o mechanizmy transmisji w czasie. Sądzę, że ostatnimi laty następuje rozwój zainteresowania przeszłością w socjologii regionalnej. Ewolucja idzie w kierunku szczegółowych pytań historycznych jako koniecznego składnika wyjaśnień i prowadzenia własnych, źródłowych badań materii historycznej. Należy zgodzić się z Robertem Traba, że studia nad lokalnościa sa szczególnie obiecujacym terenem dla rozwoju interdyscyplinarnych przedsięwzięć badawczych. Zbadanie lokalnych trajektorii zmian umożliwia uchwycenie na niewielkim wycinku wielu złożonych zależności pomiędzy czynnikami gospodarczymi, politycznymi i kulturowymi ${ }^{34}$.

Przykładem tematu, który rozwija się ciekawie w tym kierunku, jest regionalne zróżnicowanie osiagnięć edukacyjnych ${ }^{35}$. Rozkład wyników egzaminów szkolnych od dłuższego czasu wskazuje na stałą tendencję, w której badacze dostrzegaja skutki podziałów zaborowych. Chodzi o znalezienie mechanizmów, które utrwaliły te czynniki przez ponad stulecie, zapewniając im obecną żywotność i wpływ. W tym celu wywód socjologiczny został wzbogacony historyczną analizą powstawania systemów szkolnych na ziemiach polskich pod zaborami, dostępności szkół i polityki szkolnej zaborców. Opisano także różnice w społecznym statusie szkoły oraz odmienne normy społeczne wobec edukacji w każdym zaborze, stwierdzając zasadniczą przewagę Galicji w stopniu społecznej akceptacji szkoły i pozycji nauczyciela. Towarzyszył temu pozytywny stosunek do szkoły i kształcenia, które odbywało się w języku polskim i w warunkach autonomii narodowej. Ponadto na terenie zaboru austriackiego, bardziej niż w pozostałych dzielnicach rozbiorowych, edukacja stała się dźwignią awansu społecznego ${ }^{36}$. W rezultacie współczesne wyższe wyniki egzaminacyjne na obszarze dawnej Galicji znajdują wyjaśnienie w międzypokoleniowej transmisji wysiłku edukacyjnego.

Podziały zaborowe mogą pełnić rolę unikalnego laboratorium. $\mathrm{W}$ ten sposób wyjaśnia się także inne cechy kulturowe, jak na przykład różnice w intensywności praktyk religijnych czy popularności postaw demokratycznych, które utrwaliły się dzięki odmiennemu w każdym zaborze przekazowi międzypokoleniowemu ${ }^{37}$.

Wnioski można uogólniać na problemy modernizowania się społeczeństw, pokazując przebieg interakcji między różnymi typami instytucji publicznych a społecznościami w długim przedziale czasu. Takie historyczne analizy dość dokładnie chwytają związki między rodzajem infrastruktury instytucjonalnej

\footnotetext{
${ }^{34}$ Traba (2009): 238-239.

${ }^{35}$ Np. Herbst, Rivikin (2013); Herbst Kaliszewska (2017); Bukowski (2018).

${ }^{36}$ Herbst, Kaliszewska; Bukowski (2018).

${ }^{37}$ Grosfeld, Zhuravskaya 2017.
} 
a zmianami w motywacjach i działaniach ludzi. Szczegółowe trajektorie losów wspólnot regionalnych pozwalają także ujawnić sprawczość różnych podmiotów. Te przykłady nowych analiz regionalnych pokazuja, że jeśli przeszłość staje się faktycznym przedmiotem badania, to ustalenia mają szansę wyjść poza wąskie i wartościujące odczytanie przeszłości, oscylujące pomiędzy obrazami jej nieusuwalnego brzemienia lub cennej spuścizny dziejów.

Agnieszka Kolasa-Nowak

Uniwersytet Marii Curie-Skłodowskiej w Lublinie

akolasa@hektor.umcs.lublin.pl

https://orcid.org/0000-0002-5318-5171

Bartkowski, J. (2003). Tradycja i polityka. Wpływ tradycji kulturowych polskich regionów na współczesne zachowania społeczne i polityczne. Warszawa: Wydawnictwo Akademickie Żak.

Bierwiaczonek, K., Dymnicka, M., Kajdanek, K., Nawrocki, T. (2017). Miasto. Przestrzeń. Tożsamość. Studium trzech miast: Gdańsk, Gliwice, Wrocław. Warszawa: Scholar.

Bukowski, A. (2011). Region tradycyjny w unitarnym państwie w dobie globalizacji. Kraków: Wydawnictwo Uniwersytetu Jagiellońskiego.

Bukowski, P. (2018). How history matters for student performance. Lessons from the Partitions of Poland. Journal of Comparative Economics 47(1): 136-175, DOI: 10.1016/j.jce.2018.10.007.

Gąsior-Niemiec, A. (2004). Pole, habitus i imago regionis. Propozycja alternatywnego podejścia do analizy regionu. Studia Regionalne i Lokalne 4: 13-36.

Gąsior-Niemiec, A. (2013). Promocja marki regionu, czyli o dyskursywnych strategiach odwracania się od Wschodu, [w:] T. Zarycki (red.), Polska Wschodnia i orientalizm. Warszawa: Scholar: 110-133.

Gorzelak, G. (1993). Regionalizm i regionalizacja w Polsce na tle europejskim, [w:] G. Gorzelak, B. Jałowiecki (red.). Czy Polska będzie państwem regionalnym? Warszawa: Uniwersytet Warszawski, Europejski Instytut Rozwoju Lokalnego i Regionalnego: 45-70.

Gorzelak, G. (2016). Koniunktura w Polsce lokalnej. Polska gmina 2015. Warszawa: Scholar.

Gorzelak, G. (2016). Czynniki i wymiary regionalnych zróżnicowań Polski, [w:] A. Górny et al. (red.), Transformacje. Przewodnik po zmianach społeczno-ekonomicznych w Polsce. Warszawa: Scholar: 202-209.

Gorzelak, G., Jałowiecki, B. (2013). Koniunktura w Polsce lokalnej 2013. Studia Regionalne i Lokalne 58(4): 5-24.

Gorzelak, G., Tucholska, A. (2008). Historyczno-kulturowe uwarunkowania rozwoju: Polska i Ukraina. Warszawa: Scholar.

Grosfeld, I., Zhuravskaya, E. (2015). Cultural vs. economic legacies of empires: Evidence from the partition of Poland. Journal of Comparative Economics 43(1): 55-75.

Halecki, O. (1994). Historia Europy - jej granice i podziały. Lublin: Instytut Europy Środkowo-Wschodniej.

Herbst, M., Kaliszewska, A. (2017). Zabory a edukacja. Początki szkolnictwa na terytorium Polski w kontekście współczesnego zróżnicowania osiagnięć szkolnych. Studia Lokalne i Regionalne (68)2: 5-29.

Herbst, M., Rivkin, S. (2013). Divergent historical experiences and inequality in academic achievement: the case of Poland. Journal of Socio-Economics 42: 1-12.

Hryniewicz, J. (1996). Czynniki rozwoju regionalnego, [w:] B. Jałowiecki (red.), Oblicza polskich regionów. Warszawa: Uniwersytet Warszawski, Europejski Instytut Rozwoju Lokalnego i Regionalnego.

Hryniewicz, J. (2015). Polska na tle historycznych podziałów przestrzeni europejskiej oraz współczesnych przemian gospodarczych, społecznych i politycznych. Warszawa: Scholar.

Jałowiecki, B. (1996a). Wstęp, [w:] B. Jałowiecki (red.), Oblicza polskich regionów. Warszawa: Uniwersytet Warszawski, Europejski Instytut Rozwoju Lokalnego i Regionalnego.

Jałowiecki, B. (1996b). Przestrzeń historyczna, regionalizm, regionalizacja, [w:] B. Jałowiecki (red.), Oblicza polskich regionów. Warszawa: Uniwersytet Warszawski, Europejski Instytut Rozwoju Lokalnego i Regionalnego. 
Jałowiecki, B., Szczepański, M.S. (2001). Tożsamość regionalna, [w:] G. Gorzelak, B. Jałowiecki, M. Stec (red.), Reforma terytorialnej organizacji kraju: dwa lata doświadczeń. Warszawa: Uniwersytet Warszawski, Europejski Instytut Rozwoju Lokalnego i Regionalnego.

Kolasa-Nowak, A. (2011). Polska Wschodnia a socjologiczne analizy zróżnicowania regionalnego, Annales UMCS, sectio I (36)2: 71-84.

Kłoskowska, A. (1996). Kultury narodowe u korzeni. Warszawa: PWN.

Kundera, M. (1984). Zachód porwany albo tragedia Europy Środkowej. Tłum. M.L. Zeszyty Literackie 5: $14-31$

Łukowski, W. (2002). Społeczne tworzenie ojczyzn. Studium tożsamości mieszkańców Mazur. Warszawa: Scholar.

Machaj, I. (2005). Społeczno-kulturowe konteksty tożsamości mieszkańców wschodniego i zachodniego pogranicza Polski. Warszawa: Scholar.

Miłosz, C. (1990). Rodzinna Europa. Warszawa: Czytelnik.

Nijakowski, L. (2002). Dyskursy o Śląsku. Kształtowanie śląskiej tożsamości regionalnej i narodowej w dyskursie publicznym. Warszawa: Wydawnictwo Uniwersytetu Opolskiego

Ossowski, S. (1967). Dzieła. Tom 3. Warszawa: PWN.

Paasi, A. (2013). Regional planning and mobilization of 'regional identity': from bounded spaces to relational complexity. Regional Studies 47(1): 1206-1219.

Poniedziałek, J. (2011). Postmigracyjne tworzenie tożsamości regionalnej. Studium współczesnej warmińskomazurskości. Toruń: Adam Marszałek.

Rybicki, P. (1979). Struktura społecznego świata. Studia z teorii społecznej. Warszawa: PWN.

Smętkowski, M., Płoszaj, A. (2016). Porównanie metropolitalnego i historycznego wymiaru zróżnicowania polskiej przestrzeni, [w:] G. Gorzelak (red.), Polska gmina 2015. Warszawa: Scholar: $114-163$.

Soderbaum, F., Shaw, T.M. (2003). Theories of New Regionalism. London: Palgrave Macmillan.

Sosnowska, A. (1997). Tu, tam - pomieszanie. Studia Socjologiczne 4: 61-85.

Sosnowska, A. (2004). Zrozumieć zacofanie. Spory historyków o Europę Wschodnią, 1947-1994. Warszawa: Trio.

Starosta, P. (1999). Tożsamość regionalna w perspektywie socjologicznej, [w:] A. Matczak (red.), Badania nad tożsamością regionalna. Stan i potrzeby. Łódź: Krajowy Ośrodek Dokumentacji Regionalnych Towarzystw Kultury.

Synak, B. (1998). Kaszubska tożsamość. Ciągłość i zmiana. Gdańsk: Wydawnictwo Uniwersytetu Gdańskiego.

Szczepański, M.S., Ślęzak-Tazbir, W. (2009). Tropami markiza de Custine’a. Region i regionalizm w transformacyjnej Polsce, [w:] G. Gorzelak, M.S. Szczepański, W. Ślęzak-Tazbir (red.), Człowiek - miasto - region. Związki i interakcje. Warszawa: Scholar: 331-361.

Szczepański, M.S., Śliz, A. (2018). Kim jestem? Identyfikacje i tożsamości społeczne. Przypadek Górnego Śląska. Nauka 1: 129-142.

Szucs, J. (1995). Trzy Europy. Lublin: Instytut Europy Środkowo-Wschodniej.

Tatur, M. (ed.) (2004). The Making of Regions in Post-Socialist Europe: The Impact of Culture, Economic Structure and Institutions. Case Studies from Poland, Hungary, Romania and Ukraine. Volume 1. Wiesbaden: VS Verlag fur Sozialwissenschaften.

Traba, R. (2009). Przeszłość w teraźniejszości. Polskie spory o historię na początku XXI wieku. Poznań: Wydawnictwo Poznańskie.

Zarycki, T. (1999). Trwałość historycznych struktur przestrzennych na przykładzie polskiej przestrzeni politycznej, [w:] G. Gorzelak et al. (red.), Rozwój - Region - Społeczeństwo. Warszawa-Katowice: Europejski Instytut Rozwoju Regionalnego i Lokalnego: 89-102.

Zarycki, T. (2002). Region jako kontekst zachowań politycznych. Warszawa: Scholar.

Zarycki, T. (2005). Uciemiężona forpoczta Zachodu. Wiktymizacja i okcydentalizacja we współczesnym polskim dyskursie regionalnym. Kultura i Społeczeństwo 2: 115-133.

Zarycki, T. (2007). History and regional development. A controversy over the 'right' interpretation of the role of history in the development of the Polish regions. Geoforum 38: 485-493.

Zarycki, T. (2014). Ideologies of Eastness in Central and Eastern Europe. London-New York: Routledge.

Zdun, M. (2018). (Super)nowe Atlantydy. Regionalna dywersyfikacja kultur rozwoju gospodarczego. Kraków: Nomos. 


\section{THE IMPORTANCE OF HISTORY IN REGIONAL STUDIES: THE ROLE OF THE PAST IN POLISH REGIONAL SOCIOLOGY AFTER 1989}

\section{Sum mary}

Historical explanations play an important and growing role in regional studies conducted within the framework of Polish sociology. The aim of the article is to assess the scope of the uses of history and to analyse the ways of using it. I attempt to answer the following questions: what is the purpose of using the past in regional studies? What events and phenomena from the past are present in regional analyses? Is there critical reflection on how to use the past? Two areas of regional studies have been distinguished. The first is determined by analyses related to the economic dimension of regional development. The most important issues concern historical backwardness and the problem of the peripheral condition of Polish regions. The second is the study of local identities and local traditions. The past is an important component of local policies and regional discourses. There is growing critical reflection on the use of the past in managing the image of the region and creating new regional identities. References to the past serve various purposes: they justify deterministic visions and describe the durability of regional differences. They are important resources in symbolic games and the foundations of local identities. Recently, there have been new analyses in which the regional past is the subject of sociological and historical research. They search for mechanisms that connect historical institutions and practices with contemporary attitudes and actions.

Keywords: Polish regional sociology; regional past; historical sociology 